\title{
Attitude and Motivation in Learning a Local Language
}

\author{
Mulyanto Widodo \\ Language Education, Faculty of Education, Lampung Province, Indonesia \\ Farida Ariyani \\ Language Education, Faculty of Education, Lampung Province, Indonesia \\ Ag. Bambang Setiyadi \\ Faculty of Education, Lampung University, Lampung Province, Indonesia
}

\begin{abstract}
Some studies have been conducted to relate motivation with second /foreign language learning. Belmechri and Hummel (1988) introduced intensity and desire in exploring motivation in the acquisition of a second language. In some studies motivation was classified into integrative and instrumental (Gardner and Lambert, 1972; Ely, 1986; Oxford and Shearin, 1994; and Sung and Padila, 1998), while some other studies motivation was classified into extrinsic and intrinsic (Dornyei (1994; Ramage, 1990; and Noels et al. 1999). Unlike the concept of motivation introduced by Oller et al.(1977 and Spolsky ( 1969), who did not separate attitude from motivation in language learning motivation in language learning in the study is separated from attitude. This study attempted to investigate how individual differences with regard to attitude and motivation are correlated in language learning. The participants in this study consisted of 75 students of a university in Indonesia who have been learning Lampungese language, a local language, since Elementary School. The data of attitude and motivation, which were collected through questionnaires, were analyzed by undertaking correlation analyses. The findings show that attitude and motivation was significantly correlated. The pedagogical implications were also provided in this study.
\end{abstract}

Index Terms - attitude to language, attitude to language teaching, attitude to native speakers, intrinsic motivation, extrinsic motivation term

\section{INTRODUCTION}

The relationship between attitude and motivation seems to be challenging, in that different researchers have arrived at different findings. This has been due in part to different concepts and definitions of attitude and motivation and the relationships between them. In this study three types of attitude were assumed to affect language learning strategies through motivation. The three types of attitude were (1) attitudes to language, (2) attitudes to language teaching to be learned, and (3) attitudes to native speakers of a language.

It was assumed in this study that attitude affected motivation but did not directly affect language achievement. Consequently, attitude was seen not as a component of motivation but as independent factor that influences SLA through motivation (Tremblay and Gardner, 1995). The role of motivation in learning a foreign language is not questionable; some studies (Lukmani, 1972; and Olshtain et al., 1990) have shown evidence of the relationship between motivation and language proficiency. Nevertheless, different results have been provided about the role of motivation in language learning and different studies have also proposed different types of motivation. As cited in Dornyei (1994, p.213), studies on the role of attitudes and motivation in foreign language learning have been dominantly inspired by Gardner and Lambert. In their initial study, Gardner and Lambert (1972) did not separate attitude from motivation; attitudinal variables were viewed as potential determinants of motivation. Later, Gardner (1983 and 1991) formalized the concept by explicitly separating attitude from motivation. The studies on attitude and motivation, however, have arrived at different presentation of findings in relation to language learning (Oller, 1982; Els et al., 1984; Au, 1988; Skehan, 1989; and Belmechri and Hummel, 1998).

Different from the studies that viewed motivation in general (Wen and Johnson, 1997; and Olshtain et al.), in some studies students' motivation is classified into two types: instrumental and integrative motivation (see Gardner and Lambert, 1972; Ely, 1986; Oxford and Shearin, 1994; and Sung and Padilla, 1998). Instrumental motivation is defined as the desire to achieve proficiency for practical reasons while integrative motivation is defined as the desire to be like valued members of the community that speak the second language (Krashen, 1988, p. 22). The latter has often been held to be superior to the first (Gardner, 1985, p.83). The two types of motivation have been commonly used in studies on motivation related to language learning.

In this study, motivation for learning a language was assumed to involve a) the reason for learning a language and b) the degree of intention (desire) to learn a language and intensity (behavior) in learning a language. The reasons why 
students learned a language usually placed them into either integrative or instrumental motivation. In contrast, students' motivation in this study is dichotomized into internal behavior (intrinsic) or external behavior (extrinsic) connected with the reasons for learning a language. The classification consisting of intrinsic versus extrinsic seems more appropriate than that consisting of integrative and instrumental. This dichotomy was measured by referring the reason they were learning a language provided in the motivation questionnaire. The classification of motivation consisting of intention and intensity, and intrinsic versus extrinsic orientations is not new. Belmechri and Hummel (1988) conducted a study to measure intensity and desire in exploring motivation in the acquisition of a second language among high school students in Quebec City. Nevertheless, a classification consisting of integrative and instrumental motivation has been more popular in the context of foreign language learning (see Gardner and Lambert, 1972; Ely, 1986; Oxford and Shearin, 1994; and Sung and Padila, 1998), Dornyei (1994) and Ramage (1990) classified motivation into extrinsic and intrinsic. In this study the students' motivation was classified based on the reasons for learning a language whether the reason (s) are internal to the behavior (intrinsic) or external to the behavior (extrinsic). By intrinsic is meant motivation the interest in learning a language for its own sake and by extrinsic motivation is meant the interest in the language as means to other goals (Ramage, 1990, p.208). Ramage investigated factors that influence the decision to continue or discontinue foreign language study and provides data that intrinsic motivation emerged as a stronger contributor than did extrinsic motivation (p.207-8).

Unlike the concept of motivation introduced by Oller et al.(1977 and Spolsky ( 1969), who did not separate attitude from motivation in language learning, in this study, motivation in language learning is separated from attitude. How attitude, which has two sub components, is correlated with motivation, which also has two sub components. Attitude was considered primarily to be directly related to motivation and viewed as motivational support and not as a factor that has a direct effect on L2 learning, while motivation was considered to have a more direct effect on L2 learning strategies. Not many researchers on language learning have conducted studies in this field and some believe that attitude is not separated from motivation in language learning as mentioned earlier. Among the few researchers who have conducted studies on the role of attitude in language learning as separate from motivation are Kuhlemeier et al. (1996) and Svanes (1988).

This has been due in part to different concepts and definitions of attitude and motivation and the relationships between them. In this study two types of attitude were assumed to affect motivation. The two types of attitude were (1) attitudes to English and attitudes to English as a subject to be learned, and (3) attitudes to native speakers of English.

Attitude was seen not as a component of motivation but as independent factor that influences SLA through motivation (Tremblay and Gardner, 1995). The role of motivation in learning a foreign language is not questionable; some studies (Lukmani, 1972; and Olshtain et al., 1990; Zhao, 2015) have shown evidence of the relationship between motivation and language proficiency. Nevertheless, different results have been provided about the role of motivation in language learning and different studies have also proposed different types of motivation. As cited in Dornyei (1994, p.213), studies on the role of attitudes and motivation in foreign language learning have been dominantly inspired by Gardner and Lambert. In their initial study, Gardner and Lambert (1972) did not separate attitude from motivation; attitudinal variables were viewed as potential determinants of motivation. Later, Gardner (1985) formalized the concept by explicitly separating attitude from motivation. The studies on attitude and motivation, however, have arrived at different presentation of findings in relation to language learning (Oller, 1982; Els el al., 1984; Au, 1988; Skehan, 1989; and Belmechri and Hummel, 1998).

This study is meant to explore how language attitude is correlated with motivation in learning the language. Theoritically, the result of the study is expected to response whether language attitude and motivation or the two variables are separate in language learning, and practically, the result of the study is expected to to suggest language teachers how to deal with attitude to the language their students learn in order the students to have high motivation in learning a language.

\section{Methodology}

The participants of this study were 89 university students who had been enrolled at a university in Indonesia. The reason for selecting such a sample was that all subjects were learning Lampungese language, a local language in Indonesia. The students have been learning the language at school since they study at Elemenetary School. The questionnaire developed to measure language attitude consisted of 30 items. This questionnaire was arranged in a Likert- Style format. Most of the items for the questionnaire were newly developed by referring to concepts of attitude, while some items were adapted from Gardner's study (1974). The responses of strongly agree got the highest score (5) and those of strongly disagree got the lowest score (1). The questionnaire assessing motivation consisted of 40 items. In this questionnaire, students responded to statements by choosing one of three choices which were arranged ordinally. The answers are scored 3 for the highest motivated behavior and 1 for the lowest motivated behavior. Some items are negatively worded while some others are positively worded. In motivation questionnaire some items were based on the theories of motivation, while some others were also adapted from Gardner's study (1974). The questionnaire was translated into and answered in the Indonesian language.

\section{RESULT AND DISCUSSION}




\section{A. Reliability of the Measurement}

To increase the internal consistency of the hypothesized scales, Cronbach Alpha coefficients of internal consistency were computed for the scales. Language attitude (30 items; Cronbach's $\alpha=.80$ ) consists attitude to language and language learning (20 items; Cronbach's $\alpha=.82$ ) and attitude to native speakers (10 items; Cronbach's $\alpha=.86$ ). Motivation in language learning (40 items; Cronbach's $\alpha=.88$ ) consists desire to learn a language (20 items; Cronbach's $\alpha=.90$ ) and intensity in learninga language (20 items; Cronbach's $\alpha=.86$ ).

Generally, the results of the internal consistency of the measurements in this study are regarded as high and the questionnaires are acceptable for the analysis to explore the correlation between attitude and motivation in learning a language.

TABLE 1:

RELIABILITY OF THE MEASURES

\begin{tabular}{|l|l|l|}
\hline Scales & Number of items & Cronbach's alpha (n=89) \\
\hline Language attitude & 30 items & .80 \\
\hline Attitude to language and language learning & 20 items & .82 \\
\hline Attitude to native speakers & 10 items & .86 \\
\hline Motivation & 40 items & .88 \\
\hline Desire to learning a language & 20 items & .90 \\
\hline Intensity in learning a language & 20 items & .86 \\
\hline
\end{tabular}

\section{B. The Correlation of Attitude to Motivation}

As described earlier, attitude has two sub-components: attitude to language andlanguage learning, and attitude to native speakers of the language and motivation also two sub-components: desire to learn a language and intensity in learning a language. Since in this study attitude has two sub-components and so does the motivation, it will be specifically investigated how the sub-components of attitude are related to motivation and the sub-components of the motivation as well. To address the issue, correlation analysis was undertaken.

The result of correlation analysis provided in this study shows how a combination of the components of attitude was significantly correlated with motivation even though not strong $(\mathrm{r}=.26$, and $\mathrm{p}<.05)$. Attitude to language and language learning was significantly correlated with desire to learn a language with $\mathrm{r}=.33, \mathrm{p}<.01$. This component of attitude was also significantly correlated with intensity in learning a language with $\mathrm{r}=.34, \mathrm{p}<.01$. While the first component of attitude was significantly correlated with the sub-components of motivation, the second component of attitude: attitude to native speakers appeared to be not significantly correlated. This sub-component of attitude was very weakly (and not significantly) correlated with the two components of motivation: desire and intensity $(r=.04, p>.05$ and $r=.11, p>.05$ respectively).

To explore whether the first sub-component: desire to learn English was related to the second sub-component: intensity in learning English, a correlation was computed. The two sub-components had a statistically significant correlation $(\mathrm{r} .41, \mathrm{p}<.01)$. From a theoretical point of view, the correspondence between desire and intensity can be explained with the theory of reasoned action that a person's intention to perform (or not to perform) a behavior is the intermediate determinant for that action (Ajzen, 1985, p.12). The desire or intention to learn English affects the intensity or behavior in learning English. In other words, the intensity (behavior) in learning English can be predicted from the intention to learn English. They seem to have a close and predictive relationship as suggested in this study.

That the sub-component attitude to language and language learning is correlated with both of the sub-components of motivation may imply that the two individual variables have a cause-and-effect relationship. Logically, it may be argued that it is more likely that attitude is the cause than the effect. Attitude seems to be the cause and motivation to be the effect in the relationship. This tentative answer was drawn on a theoretical ground that attitudes influence the effort that students expend to learn another language; the effort expended to learn another language has to do with actions and intentions related to the attitudinal object (Mantle-Bromley, 1995, p.373). The actions refer to intensity in this study and intentions to desire in learning Indonesian language.

TABLE 2:

CORRELATION AMONG THE COMPONENTS OF ATTITUDE AND MOTIVATION

\begin{tabular}{|l|l|l|l|l|l|l|}
\hline $\mathrm{N}=79$ & $\mathrm{~A}$ & $\mathrm{~A} 1$ & $\mathrm{~A} 2$ & $\mathrm{M}$ & $\mathrm{M} 1$ \\
\hline $\mathrm{A}$ & & $.58^{* *}$ & $.89^{* *}$ & .14 & $.26^{*}$ & $.19^{*}$ \\
\hline $\mathrm{A} 1$ & $.58^{* *}$ & & & $.40^{* *}$ & $.25^{* *}$ & $.33^{* *}$ \\
\hline $\mathrm{A} 2$ & $.89^{* *}$ & .14 & .09 & .09 & .04 \\
\hline $\mathrm{M}$ & $.26^{*}$ & $.40^{* *}$ & $.34^{* *}$ & .16 & $.86^{* *}$ \\
\hline $\mathrm{M} 1$ & $.19^{*}$ & $.34^{* *}$ & .04 & $.86^{* *}$ & $.82^{* *}$ \\
\hline $\mathrm{M} 2$ & $.25^{* *}$ & .16 & $.82^{* *}$ & $.41^{* *}$ & $.41^{* *}$ \\
\hline
\end{tabular}

**.Correlation is significant at the $0.01, *$.Correlation is significant at the 0.05 Note:

$A=$ Attitude $\quad \mathrm{A} 1=$ Attitude to the language and the language learning; $\quad \mathrm{A} 2=$ Attitude to native speakers

$\mathrm{M}=$ Motivation; $\quad \mathrm{M} 1=$ Desire to learn the language; $\quad$ M2 = intensity in learning the language 
It is interesting to note that attitude to the target language and learning the language are significantly correlated with either motivation or its components while attitude to native speakers of Lampungese is not. It may imply that some components of language attitude, in particular attitude to the target language and attitude to learning the target language is a part of motivation in language learning. It may also suggest that attitude is not necessarily a part of motivation in learning a language. Probably, this alo suggests that although attitudes to native speakers may affect motivation in learning a language whenever learners wish to integrate themselves into the culture of the new language, the condition or opportunity to integrate into the culture of the target language seems very rare in Indonesia. This may also imply that language attitude to Lampungese and learning Lampungese is more correlated with motivation than is attitudes to native speakers of Lampungese. The above issues provided with the findings of this study need further research.

\section{CONCLUSION AND SugGestion}

The teacher may provide opportunities for the students to have positive attitude, especially attitude to lampungese and to lampungese learning. Hopefully, by having the students with positive attitude, the Lampungese teachers can provide opportunities for the students to have high motivation. The individual differences in attitude and motivation can be expected to produce greater frequency of learning strategy use, which has been investigated and revealed in many studies to be significantly correlated with language achievement and contribute to the success.

\section{ApPEndix 1. AtTitude Questionnaire}

Following are a number of statements with which some people agree and others disagree. There are no right or wrong answers since many people have different opinions. We would like you to indicate your opinions about each statement by ticking the alternative below which best indicates the extent to which you agree or disagree with that statement.

\begin{tabular}{|c|c|c|c|c|c|c|}
\hline No & Statements & Strongly agree & Agree & Can't decide & Disagree & Strongly disagree \\
\hline 1 & Lampungese is necessary in the era of globalization & & & & & \\
\hline 2 & Lampungese is a language with standard rule & & & & & \\
\hline 3 & $\begin{array}{l}\text { In Indonesia the use of Lampungese should be } \\
\text { restricted. }\end{array}$ & & & & & \\
\hline 4 & Lampungese is a popular language in Indonesia & & & & & \\
\hline 5 & $\begin{array}{l}\text { Television programs shown in Lampungese in } \\
\text { Indonesia must be translated into Indonesian }\end{array}$ & & & & & \\
\hline 6 & $\begin{array}{l}\text { Lampungese is less important than other foreign } \\
\text { languages for Indonesians }\end{array}$ & & & & & \\
\hline 7 & Lampungese is a very complicated language & & & & & \\
\hline 8 & Lampungese is a language of educated people & & & & & \\
\hline 9 & Listening to Lampungese songs is disgusting & & & & & \\
\hline 10 & Lampungese pronunciation is beautiful & & & & & \\
\hline 11 & Learning Lampungese is obligatory in this province & & & & & \\
\hline 12 & $\begin{array}{l}\text { If I have children, I would like them also to learn } \\
\text { Lampungese out of school hours }\end{array}$ & & & & & \\
\hline 13 & $\begin{array}{l}\text { I prefer to be taught Lampungese at all school } \\
\text { levels. }\end{array}$ & & & & & \\
\hline 14 & Learning Lampungese is interesting. & & & & & \\
\hline 15 & Learning Lampungese makes me happy. & & & & & \\
\hline 16 & $\begin{array}{l}\text { I would rather spend my time on another language } \\
\text { (if any) than Lampungese. }\end{array}$ & & & & & \\
\hline 17 & Learning Lampungese is dull & & & & & \\
\hline 18 & Lampungese class should be an optional subject & & & & & \\
\hline 19 & Lampungese is a language worth learning & & & & & \\
\hline 20 & $\begin{array}{l}\text { Learning Lampungese can influence our way of life } \\
\text { based on our country }\end{array}$ & & & & & \\
\hline 21 & Native speakers of Lampungese are friendly & & & & & \\
\hline 22 & $\begin{array}{l}\text { Native speakers of Lampungese are generally well } \\
\text { educated }\end{array}$ & & & & & \\
\hline 23 & $\begin{array}{l}\text { Native speakers of Lampungese feel too superior to } \\
\text { other people }\end{array}$ & & & & & \\
\hline 24 & Native speakers of Lampungese are money oriented & & & & & \\
\hline 25 & Native speakers of Lampungese are arrogant & & & & & \\
\hline 26 & $\begin{array}{l}\text { Native speakers of Lampungese tend to intervene } \\
\text { another country's domestic affairs }\end{array}$ & & & & & \\
\hline 27 & Native speakers of Lampungese are trustworthy & & & & & \\
\hline 28 & Native speakers of Lampungese are hard working & & & & & \\
\hline 29 & $\begin{array}{l}\text { Native speakers of Lampungese are considerate of } \\
\text { the feeling of others }\end{array}$ & & & & & \\
\hline 30 & Native speakers of Lampungese are selfish & & & & & \\
\hline
\end{tabular}




\section{APPENDix 2. MOTIVATION QUESTIONNAIRE}

\section{Instruction}

Please answer each of the following items by circling the letter of the alternatives which appear to most applicable to you. We hope you to be as accurate as possible since the success of this investigation depends on it.

1. Why do I learn Lampungese?. I can honestly say that I
a. try to kill my spare time.
b. am suggested by somebody else to join.
c. really try to learn Lampungese.

2. If my Lampungese teacher wants someone to do an extra Lampungese assignment, I will
a. definitely volunteer
b. only do it if he/she asks me directly
c. definitely not volunteer

3. When I hear Lampungese songs on the radio, I
a. change the station.
b. prefer to listen to the music, paying attention only to the easy words.
c. prefer to listen carefully and try to understand all the words.

4. If I have Lampungese homework, I
a. just skim over it
b. put some effort into it, but not as much as I could.
c. work very carefully, making sure I understand everything.

5. When I see directions written in Lampungese, I
a. read them carefully and try to understand.
b. read them over, but give up if it gets difficult.
c. look for the Indonesian translation.

6. If I have a problem in understanding something while I am learning Lampungese, I
a. just forget about it.
b. only seek help just before the exam.
c. immediately ask the teacher for help.

7. I actively think about what I have learned in the Lampungese course
a. very frequently
b. once in a while
c. hardly ever

8. When I am in the Lampungese discussion, I
a. never say anything.
b. speak once a while.
c. speak quite often.

9. Outside of class I read Lampungese books and magazines.
a. quite often
b. once a while
c. never

10. After I get my Lampungese assignment back, I
a. always rewrite them, correcting my mistakes.
b. look them over, but I don't bother correcting mistakes.
c. just throw them in my bag and forget it.
11. If an Lampungese course is offered, I will
a. not enroll in the course.
b. enroll if it is free.
c. definitely enroll.

12. If I have an opportunity to speak Lampungese outside class, I will
a. speak it most the time if it is possible.
b. speak it occasionally if it is necessary.
c. never speak it.

13. During the Lampungese class, I would like
a. to have only Lampungese spoken.
b. to have a combination of Indonesian and Lampungese spoken.
c. to have Indonesian spoken as much as possible.

14. If I had opportunity to meet Lampungese speaking families, I would
a. not go.
b. go only if I had nothing to do.
c. definitely go. 
15. If I had a choice, I would like to take
a. a Lampungese class only.
b. a Lampungese and another local language class.
c. another local language class.

16. If there were a Lampungese speaking club here, I would
a. try to attend the meetings as often as possible.
b. attend the meeting only once a while.
c. not join.

17. If I knew enough Lampungese, I would watch Lampungese Television programs
a. as often as possible.
b. sometimes.
c. never.

18. If I had opportunity and knew enough Lampungese, I would read Lampungese books and magazines
a. never.
b. not very often.
c. as often as possible.

19. After I finish my Lampungese class, I will probably
a. make no attempt to remember the Lampungese I have learned.
b. try to use the Lampungese that I am very sure of.
c. try to use Lampungese as much as possible.

20. If there were a Lampungese television station, I would
a. never watch it.
b. turn it on occasionally.
c. try to watch it often.

21. Why do I learn Lampungese? I can honestly say that I
a. try to kill my spare time.
b. am suggested by somebody else to join.
c. really try to learn English.

22. If my Lampungese teacher wants someone to do an extra Lampungese assignment, I will
a. definitely volunteer
b. only do it if he/she asks me directly
c. definitely not volunteer

23. When I hear Lampungese songs on the radio, I
a. change the station.
b. prefer to listen to the music, paying attention only to the easy words.
d. prefer to listen carefully and try to understand all the words.

24. If I have Lampungese homework, I
a. just skim over it.
b. put some effort into it, but not as much as I could.
c. work very carefully, making sure I understand everything.

25. When I see directions written in Lampungese, I
a. read them carefully and try to understand.
b. read them over, but give up if it gets difficult.
c. look for the Indonesian translation.

26. If I have a problem in understanding something while I am learning Lampungese, I:
a. just forget about it.
b. only seek help just before the exam.
c. immediately ask the teacher for help.

27. I actively think about what I have learned in the Lampungese course...
a. very frequently
b. once in a while
c. hardly ever

28. When I am in the Lampungese discussion, I
a. never say anything.
b. speak once a while.
c. speak quite often.

29. Outside of class I read Lampungese books and magazines.
a. quite often
b. once a while
c. never 
30. After I get my Lampungese assignment back, I

a. always rewrite them, correcting my mistakes.

b. look them over, but I don't bother correcting mistakes.

c. just throw them in my bag and forget it.

31. If an Lampungese course is offered, I will
a. not enroll in the course.
b. enroll if it is free.
c. definitely enroll.

32. If I have an opportunity to speak Lampungese outside class, I will
a. speak it most the time if it is possible.
b. speak it occasionally if it is necessary.
c. never speak it.

33. During the Lampungese class, I would like
a. to have only English spoken.
b. to have a combination of Indonesian and English spoken.
c. to have Indonesian spoken as much as possible.

34. If I had opportunity to meet Lampungese speaking families, I would
a. not go.
b. go only if I had nothing to do.
c. definitely go.

35. If I had a choice, I would like to take
a. a Lampungese class only.
b. a Lampungese and another foreign language class.
c. another local language class.

36. If there were a Lampungese speaking club here, I would
a. try to attend the meetings as often as possible.
b. attend the meeting only once a while.
c. not join.

37. If I knew enough Lampungese, I would watch Lampungese Television programs
a. as often as possible.
b. sometimes.
c. never.

38. If I had opportunity and knew enough Lampungese, I would read Lampungese books and magazines
a. never.
b. not very often.
c. as often as possible.

39. After I finish my Lampungese class, I will probably
a. make no attempt to remember the Lampungese I have learned.
b. try to use the Lampungese that I am very sure of.
c. try to use Lampungese as much as possible.

40. If there were a Lampungese television station, I would:
a. never watch it.
b. turn it on occasionally.
c. try to watch it often.

\section{REFERENCES}

[1] Ajzen, Icek. (1985). From intentions to actions: A theory of planned behavior. In Julius Kuhl and Jurgen Beckmann (Eds.), Action control: from Cognition to behavior, pp. 11-19. Berlin Heidelberg: Springer-Verlag.

[2] Au, Shun Y. (1988). A critical appraisal of Gardner's social-psychological theory of second language (L2) learning. Language Learning, Vol.38, No.1, 75-94.

[3] Belmecheri, Faiza and Hummel, Kirsten. (1988). Orientations and motivation in the acquisition of English as a second language among high school students in Quebec City. Language Learning, 48:2, 219-244.

[4] Dornyei, Zoltan. (1994). Motivation and motivating in the foreign language. The Modern Language Journal, 78, iii, 273-284.

[5] Dornyei, Zoltan. (1998). Motivation in second and foreign language learning. Language Teaching, 31, 117-135.

[6] Els, Theo van, Bongaerts, Extra, Guus, van Os, Charles and Janssen-van Dieten, Anne-Mieke. (1984). Applied linguistics and the learning and teaching of foreign languages. Victoria: Edward Arnold Pty.

[7] Ely, Christopher M. (1986). Language learning motivation: a descriptive and causal analysis. The Modern Language Journal, 70, I, 28-35.

[8] Gardner, R.C. and Lambert, W.E. (1972). Attitudes and motivation in second language learning. Massachusetts: Newbury House Publisher. 
[9] Gardner, R.C. (1974). Second language acquisition: a social psychological approach (final report). Ontario: Ministry of Education

[10] Gardner, R.C. (1985). Social psychology and second language acquisition: the role of attitudes and motivation. Maryland-USA: Edward Arnold.

[11] Krashen, Stephen D. (1985). The input hypothesis: Issues and implications. New York: Longman Inc.

[12] Kuhlemeier, Hans, Van Den Berg, Huub and Melse, Leijn. (1996). Attitudes and achievements in the first year of German language instruction in Dutch secondary school education. The Modern Language Journal, 80, IV, 494-508.

[13] Lukmani, Yasmeen M. (1972). Motivation to learn and language proficiency. Language Learning, Vol.22, No.2, 261-273.

[14] Mantle-Bromley, Corinne. (1995). Positive attitude and realistic beliefs: links to proficiency. The Modern language Journal, 79 , iii, 372-386.

[15] Noels, Kimberly A., Clement, Richard and Pelletier, Luc G. (1999). Perceptions of teachers' communicative style and students' intrinsic and extrinsic motivation. The Modern Language Journal, 83, I, pp.22-33.

[16] Oller, John, Baca, Lori, and Vigil, Fred. (1977). Attitudes and attained proficiency in ESL: a sociolinguistic study of Mexican Americans in the Southeast. TESOL Quarterly, Vol. 11, No2, 175-184.

[17] Oller, John W. (1982). Gardner on effect: a reply to Gardner. Language Learning, Vol.32, No.1, 183-190.

[18] Olshtain, Elite, Shohamy, Elana, Kemp, Judy, and Chatow, Rivka. (1990). Factors predicting success in EFL among culturally different learners. Language Learning, Vol 40, No.1, 23-44.

[19] Oxford, Rebecca and Shearin Jill. (1994). Language learning motivation: expanding the theoretical framework. The Modern Language Journal, 78, I, 12-28.

[20] Ramage, Katherine. (1990). Motivational factors and persistence in foreign language study. Language Learning, 40:2, 189-219.

[21] Skehan, Peter. (1989). Individual differences in second language learning. London: Hoddor and Stoughton Limited.

[22] Spolsky,Bernard. (1969). Attitudinal aspects of second language. Language Learning, Vol.XIX, Nos. 3 \& 4, $271-283$.

[23] Sung, Hyekyung and Padilla, Amadom. (1998). Student motivation, parental attitudes, and involvement in the learning of Asian languages in elementary and secondary Schools. The Modern Language Journal, 82, ii, 205-216.

[24] Svanes, Bjorg. (1988). Attitudes and cultural distance in second language acquisition. Applied Linguistics, Vol. 9, No.4, 357371.

[25] Trembley, Paul F. and Gardner, Robert C. (1995). Expanding the motivation construct in language learning. The Modern Language Journal, 79, IV, 505-518.

[26] Wen, Qiufang and Johnson, Keith Robert. (1997). L2 learner variables and English achievement: a study of tertiary-level English majors in China. Applied Linguistics, Vol.18, No. 1, 27-48.

[27] Zhao, Lili. (2015). The Influence of Learners' Motivation and Attitudes on Second Language Teaching. Theory and Practice in Language Studies, Vol. 5, No. 11, pp. 2333-2339.

Mulyanto Widodo is a lecturer in the Department of Language Education, Faculty of Education, Lampung University. His researches mainly include Indonesian language teaching and linguistics. He has published several books and papers.

Farida Ariyani is a lecturer in Lampungese studies at the Department of Language Education. She has taught Lampungese courses at the Faculty of Education, Lampung University, Indonesia. Her research interests include second language acquisition, communication strategies as well as intercultural communication.

Ag. Bambang Setiyadi is a lecturer presenting courses in language teaching methodology and research methodology at the Department of English Language of Lampung University, Indonesia. He has presented and published nationally and internationally on issues related to language teaching and learning. 